\title{
APPLICATION OF STEM-BASED ON FLIPPED LEARNING IN NATURAL SENSITIVITY COURSES
}

\author{
Submitted: \\ 17 September 2021 \\ Accepted: \\ 8 Desember 2021 \\ Published: \\ 31 Januari 2022
}

\author{
M. Misbachul huda*1, Adhy Putri Rilianti ${ }^{2}$ \\ mizzzbach@gmail.com ${ }^{1}$, adhyputrir@gmail.com ${ }^{2}$ \\ PGSD, STKIP Al Hikmah Surabaya ${ }^{1,2}$ \\ *Corresponding Author
}

\begin{abstract}
The research aims to describe the application of flipped learning-based STEM in Sensitivity to Nature courses for PGSD students. The method used in this research is descriptive qualitative. The research data is described in the form of a description that describes the application of STEM-based on Flipped Learning in Sensitivity of Nature course. The application of STEM-based flipped learning in Sensitivity of Nature courses is carried out in 4 phases, the independent learning phase through LMS, the phase of completing assignments in the online class, the discussion phase in the online class, and the understanding test phase in the class through the LMS. STEM components are mapped based on the constituent subjects of STEM, science, technology, engineering, and mathematics. The results of mapping become a reference in the preparation of lecture materials and activities. The results of this study imply that the application of STEM-based flipped learning can be applied to courses that have a relationship with STEM subjects.
\end{abstract}

Keywords: STEM, flipped learning, nature sensitivity.

\section{INTRODUCTION}

The Nature Sensitivity course in the Academic Manual of PGSD STKIP Al Hikmah Surabaya (2018) examined future science materials and learning as well as environmental and global environmental problems. The topics discussed lead to the projection of nature in the future and the problems that continue to arise. This requires the lecture process carried out to be able to explore lecture topics from various perspectives. One approach that can be applied to accommodate the achievement of a complete view of a topic is the STEM approach. Moore et al (2014) stated that STEM is an approach and effort in integrating several STEM subjects based on relationships between subjects and real-world problems. Subjects in STEM include Science, Technology, Engineering, and Mathematics. 
Subjects combination in STEM makes it easier for students to achieve one of the competencies required in the Nature Sensitivity course, which is the ability of students to solve problems. Students who have abilities based on STEM subjects can develop good strategies in dealing with complex situations to produce a solution (Basham \& Marino, 2013). Science is knowledge of nature that contains facts, concepts, procedures from the disciplines of physics, biology, chemistry. Technology is a system that involves the use of scientific products. Engineering is engineering knowledge by utilizing concepts from science. Mathematics is the knowledge that relates various quantities, numbers, and spaces. The combination of the four STEM fields encourages the knowledge received to be more meaningful when integrated into the lecture process.

During the Covid-19 pandemic which began in early 2020, the lecture process implemented full online learning. Several learning models are applied to provide an interesting lecture process so that students can achieve competence in each subject, including the Nature Sensitivity course. Various models in online learning include blended learning, distance learning, and flipped learning (Hamdan \& Knight, 2013). These various learning models aim to provide innovation in responding to the form of lectures that have changed from face-to-face in the classroom to online lectures, both in the form of virtual face-to-face and based on the Learning Management System (LMS). One of the online learning models that have been widely studied is flipped learning. The principle of learning in the flipped learning model is that activities that are usually carried out outside meeting hours are better carried out in class meetings. Furthermore, listening to the lecturer's explanation can be done independently outside of lectures through videos that are loaded on online learning platforms or other online broadcast media. In flipped learning, the presentation of the material is given outside of face-to-face before learning begins, while assignments or discussions are carried out face-to-face on the learning schedule (Bergman \& Sams, 2012).

A thorough study of the STEM component has a weakness, that it is needed a longer time in the learning process. This weakness can be overcome by implementing a learning process that systematically combines activities during and outside of learning, namely flipped learning. The application of STEM-based flipped learning has optimal steps in online learning. An attractive presentation in an online platform provides a new alternative in structuring the latest learning. Therefore, the purpose of this study was to 
describe the application of STEM-based flipped learning in the Nature Sensitivity course at the S1 Elementary School Teacher Education Study Program (PGSD) STKIP Al Hikmah Surabaya.

This study aims to describe the application of flipped learning-based STEM in Nature Sensitivity courses for PGSD students. Flipped learning is implemented in 4 phases, they are Phase 0 in the form of students learning independently, phase 1 students attending class to learn and complete the assigned tasks, phase 2 students applying their abilities in a project assignment or simulation in class, and phase 4 understanding students are tested with tests conducted in class at the end of the subject matter (Bishop, 2013). Through these four phases, it is hoped that the advantages of flipped learning provide opportunities for students to actively participate in learning. The advantages of flipped learning are increasing discussion time in class, providing flexible learning opportunities, a student-centered learning experience, there is more interaction between students and lecturers, increased learning motivation, and more varied learning resources (Basal, 2015).

\section{METHOD}

This research used the descriptive qualitative method. The data collected are various systematic phenomena in the application of STEM-based on Flipped Learning in the Nature Sensitivity course. The subjects of this study were 6th-semester students of Nature Sensitivity course programmers at the S1 Elementary School Teacher Education Study Program, STKIP Al Hikmah Surabaya. The research lasts for one semester, which is the even semester of the 2020-2021 academic year. In this study, researchers were directly involved in the application of STEM-based Flipped Learning.

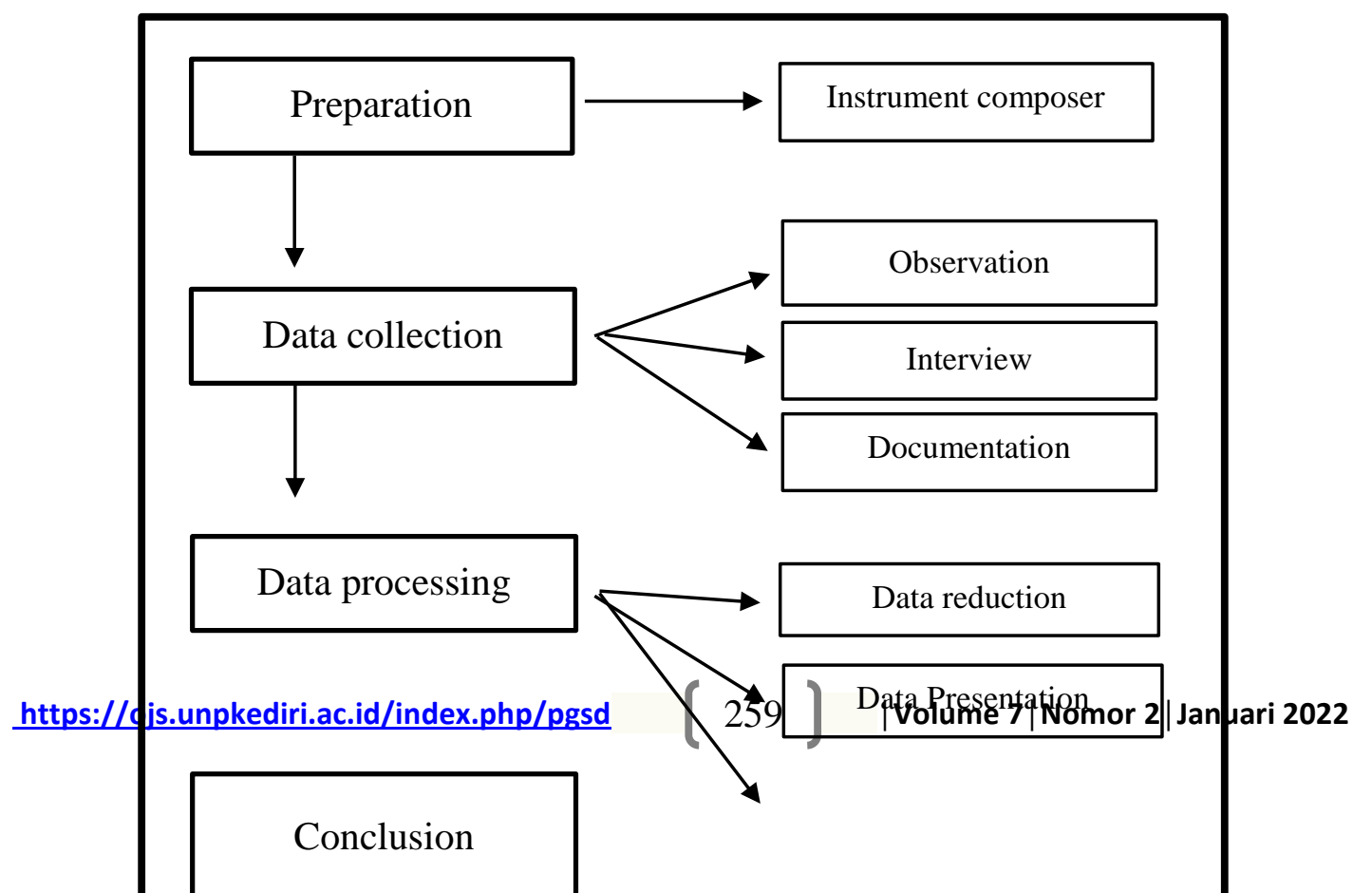




\section{Figure 1. Research Procedure}

The research procedure includes the preparation stage, data collection, data processing, and conclusion drawing. Data collection techniques using the method of observation, interviews, and documentation. The research instrument was an observation sheet on the implementation of learning and an interview sheet. Data analysis was carried out by data reduction, data presentation, and concluding (Miles \& Hubberman, 2012). Testing the validity of data is done by using the data triangulation technique, namely source triangulation. The research procedure is presented in Figure 1.

\section{RESULTS}

The application of flipped learning-based STEM begins with the preparation of the Semester Lecture Plan (RPS) in the Nature Sensitivity course. Based on the results of interviews and documentation, on each topic of lecture studies, the STEM components are mapped in the form of tables that contain each material in each STEM component. For example, at meeting 2, the topic of the lecture study was an earthquake, so facts, concepts, or an application related to the topic of earthquakes were chosen. The science component on the topic of earthquakes is the concept of the occurrence of earthquakes, types of earthquakes, and the impact of earthquakes on the environment and living things. The technology component is a web-based earthquake zoning map in Indonesia with the name Spektra Indonesia. Engineering components in the form of how the seismograph works is a tool used to measure the strength of an earthquake. The mathematical component is an interval of earthquake strength on the Richter scale which is generated from a mathematical equation. In summary, the mapping of STEM components at the initial five meetings is presented in Table 1.

Table 1. Mapping of STEM Components in Nature Sensitivity Courses

\begin{tabular}{|l|l|l|l|l|} 
Topic & Science & Technology & Engineering & Math \\
\hline
\end{tabular}




\begin{tabular}{|c|c|c|c|c|}
\hline Earthquake & $\begin{array}{c}\text { The process of } \\
\text { occurrence, type, } \\
\text { and } \\
\text { earthquake impact }\end{array}$ & $\begin{array}{l}\text { Indonesian } \\
\text { Spectra }\end{array}$ & $\begin{array}{c}\text { How a } \\
\text { seismograph } \\
\text { works }\end{array}$ & $\begin{array}{l}\text { Earthquake } \\
\text { magnitude }\end{array}$ \\
\hline Landslide & $\begin{array}{l}\text { process occurs, } \\
\text { types, and impacts } \\
\text { of landslides }\end{array}$ & inclinometer & $\begin{array}{c}\text { Slope area } \\
\text { management } \\
\text { design } \\
\end{array}$ & Land tilt angle \\
\hline $\begin{array}{l}\text { volcano } \\
\text { eruption }\end{array}$ & $\begin{array}{l}\text { The process of } \\
\text { occurrence, type, } \\
\text { and } \\
\text { the impact of a } \\
\text { volcano erupting }\end{array}$ & $\begin{array}{c}\text { Arduino } \\
\text { Microcontroller } \\
\text { Based Early } \\
\text { Warning System }\end{array}$ & Tiltmeter & $\begin{array}{c}\text { Volcanic } \\
\text { Explosivity Index } \\
\text { (VEI) }\end{array}$ \\
\hline Tsunami & $\begin{array}{l}\text { The process of } \\
\text { occurrence, } \\
\text { impact, and } \\
\text { efforts to reduce } \\
\text { the impact of the } \\
\text { Tsunami }\end{array}$ & INATEWS & $\begin{array}{c}\text { Beach Area } \\
\text { Building Design }\end{array}$ & $\begin{array}{l}\text { Tsunami } \\
\text { Numerical } \\
\text { Modeling }\end{array}$ \\
\hline Coastline & $\begin{array}{l}\text { Definition, causes } \\
\text { of change and } \\
\text { their effects }\end{array}$ & Remote Sensing & $\begin{array}{l}\text { Measurement of } \\
\text { Shoreline Change }\end{array}$ & $\begin{array}{l}\text { Generalized } \\
\text { Model for } \\
\text { Shoreline } \\
\text { simulation }\end{array}$ \\
\hline
\end{tabular}

\section{Source: Doc. Writer}

The next preparation is an organization of LMS with a Schoology platform to implement flipped learning. Based on the results of interviews and documentation, the LMS is arranged in folders according to the number of topics or meetings for natural sensitivity courses. There are 14 study topics and 2 summative assessments. On each topic, lecture material is provided outside of face-to-face online lecture hours. Presentation of material in the form of powerpoint material and a video explanation of the material or video learning. Folders presentation and activities on each topic are arranged according to the schedule of the lecture plan. The purpose of the broadcast arrangement is to allow students to listen to reference material before the online face-toface lecture is held. The presentation of lecture material on LMS is shown in Figure 1 below. 


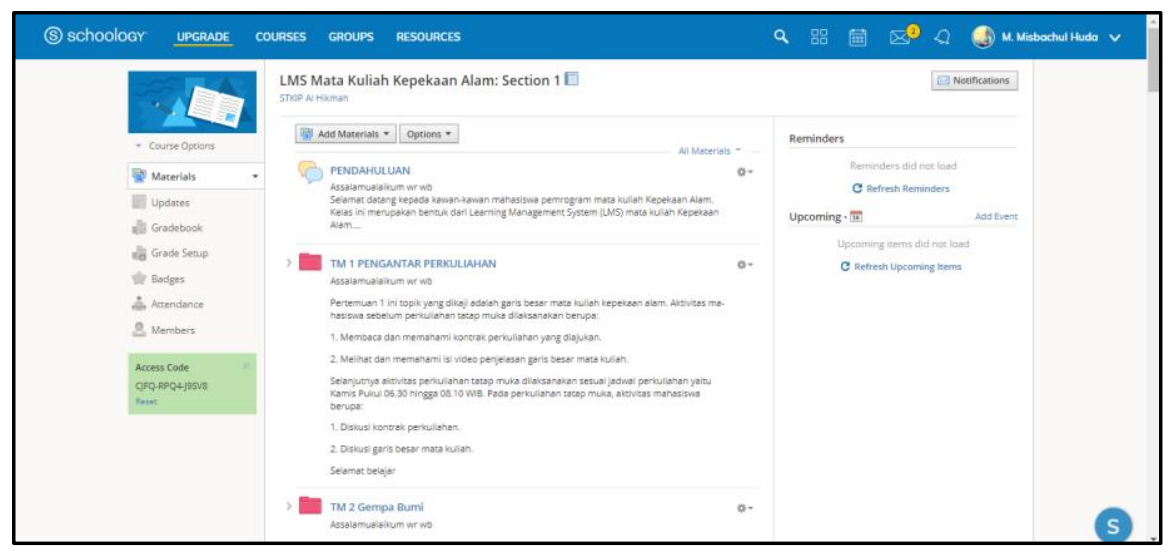

Figure 2. Presentation of Flipped Learning in LMS

Source: Doc. Writer

Reminders to students the day before the lecture which is equipped with a link to attend the online face-to-face lecture. Based on the interview results and documentation, with the lecture link being distributed the day before the face-to-face lecture, it encourages students to prepare for a better lecture process. Another benefit of having a reminder is to remind students to listen to the reference material presented by the course lecturer. Students can write notes or even compose a mind map of lecture material at this stage.

In phase 0 , students learn independently, the time to access reference material in the LMS is not limited. Students can determine independently the best time to listen to lecture material references. Based on observations and documentation, not all students listened to the material that had been presented in the LMS completely. Network constraints are the main cause of this finding. Some students have experienced blackouts, so when the time for lectures arrives, they are not involved in online lecture activities.

At the implementation stage, lecture activities are in the form of project completion and discussions, both discussions between students and students with the course lecturer. At this stage, phase 1 to phase 3 of flipped learning is also carried out. During the discussion session, questions often arise from students related to technology and mathematics components. Students need repetition to better understand the two difficult STEM components. 
Phase 1, learning activities are carried out in online classes using the zoom meeting room platform, students are divided into several groups randomly to do tasks related to the material that has been studied at home and are also asked questions at the beginning of learning to measure students' initial understanding when studying independently. Furthermore, in phase 2, the chosen lecture activity is to conduct discussions in groups that are arranged randomly. The lecturer's role is to facilitate discussion. The lecturer also prepares several questions from the material studied in each topic, then what is meant by projects in this learning session are activity sheets that are completed or tried by students to apply their understanding abilities.

Based on the results of observations and documentation, in learning activities, there is an increase in aspects of student attitudes and skills in applying the concepts studied, as well as being more actively involved in problem-solving activities. In the face-to-face phase in flipped learning, students are more confident in classroom activities, ready to accept learning activities with better motivation than the usual learning model. This shows that flipped learning-based learning can increase students' motivation, activeness, and learning skills (Damayanti and Sutama, 2016).

In the last phase, based on the results of interviews and observations, students do questions that test their understanding during face-to-face learning activities. The teacher acts as a facilitator in this phase 3 . The questions are in the form of quizzes that are packaged in an integrated manner in the LMS of the Nature Sensitivity course. This feature provides various forms of questions that the lecturer can choose according to their needs. The following is a display of the contents of the LMS in the application of STEM-based flipped learning in the Nature Sensitivity course. 


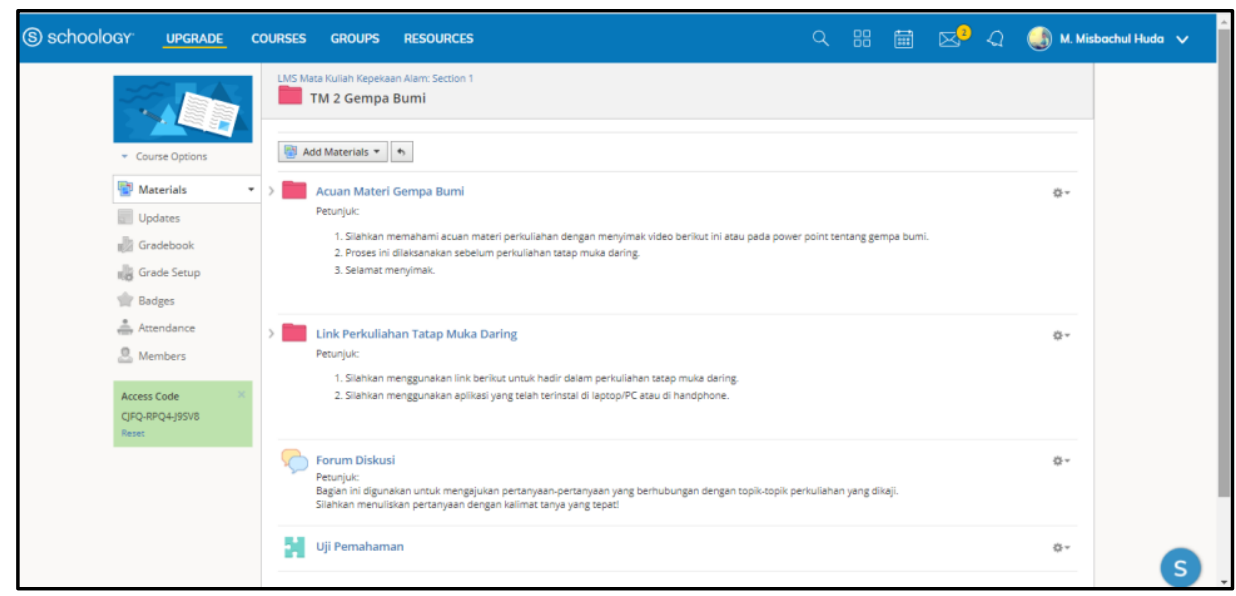

Figure 2. Format of LMS Content for Nature Sensitivity Course

Source: Doc. Writer

\section{DISCUSSION}

The preparation stage is the application of STEM-based flipped learning, which is an activity carried out to provide a reference for STEM material that will be accessed by students starting before lectures until face-to-face lectures. The lecture materials organization combines STEM components, that is science, technology, engineering, and mathematics. The integrated application of STEM in learning can improve students' academic and non-academic achievements (Lou, IU, \& Shih, 2011). At this stage, material and lecture activities have been mapped following each STEM component. STEM learning is an integration of Science, Technology, Engineering, and Mathematics and the four disciplines should not be taught separately (Torlakson, 2014).

Reference material in the form of power points and learning videos uploaded to the LMS before lectures. The reference material becomes the student's self-study material before a face-to-face lecture is carried out. Independent learning is one component in the application of flipped learning. Independent learning is defined as an activity of a learner at a different place and time with class conditions (Chaeruman, 2018). Flipped learning has the main characteristic of reversing the learning process, that is from ordinary learning to learning that presents material before face-to-face classes and provides activities that are carried out together during face-to-face activities (Bergmann \& Sams, 2012). 
There are 4 phases in the application of STEM-based on flipped learning, they are the independent learning phase through the LMS, the phase of completing assignments in the online class, the discussion phase in the online class, and the understanding test phase in class through the LMS. This phase is following the flipped learning step according to Bishop \& Verleger (2013). The four phases of flipped learning are in line with the steps of flipped learning according to Basal (2015), namely planning material references, selecting class activities, selecting task models, and presenting student assignments. Subagia (2017) also stated that the steps for implementing flipped learning are independent learning at home, the formation of random groups, class discussions, and comprehension tests.

The independent learning phase through LMS is a step to provide students with knowledge about the topic being studied. This is following the learner-based learning paradigm so that students are more active in the process of knowledge formation (Hamdan \& Knight, 2013). Independent learning activities provide opportunities for students to carry out the reasoning process which is an important process in problemsolving (Khan \& Ullah, 2010).

The task completion phase in an online class is carried out for 2 credits according to the weight of the Nature Sensitivity course. The interaction process occurs between students and between students and courses lecturers. flipped learning has a fundamental goal to enable more effective use of time in the classroom and teachers can directly provide feedback to students (Lo and Hew, 2017). The interaction process that aims to solve a problem requires the application of knowledge that has been obtained and testing it. This competency is appropriate to the competency needs of students in facing 21st-century life (Maolidah et al, 2017). In this phase, the principle is to reduce the capacity of learning activities in the classroom by optimizing interactions between students and also students and lecturers (Johnson, 2013).

The discussion phase in the online class was carried out in the form of a presentation and continued with the discussion process. This stage requires various communication skills and the application of knowledge from students. Flipped learning provides various advantages and challenges in learning, the benefits that can be obtained include increasing online learning interactions, increasing interest, and increasing professional abilities (Ilgu, et al, 2017). The existence of a discussion phase 
in class can improve students' creative attitudes, responsibility, and learning skills (Damayanti \& Sutama, 2016).

The understanding test phase in the classroom through the LMS aims to test students' understanding of each topic. In flipped learning, the assessment is not only carried out at the end of competency but is carried out during the learning process in the classroom. Formative and summative assessments should be included in meaningful face-to-face learning activities (Enfield, 2013). A comprehensive assessment is an integral part of flipped learning, this activity includes assessing the understanding process, the application process, and analyzing through presentation activities (Zhou, 2014).

\section{CONCLUSION}

The application of flipped learning-based STEM in Nature Sensitivity courses is carried out in 4 phases, namely the independent learning phase through the LMS, the phase of completing assignments in the online class, the discussion phase in the online class, and the understanding test phase in the class through the LMS. STEM components are mapped based on the constituent subjects of STEM, namely science, technology, engineering, and mathematics. The results of the mapping become a reference in the preparation of materials and activities for Nature Sensitivity lectures. The application of STEM-based flipped learning uses a Schoology platform as an LMS and a zoom meeting room as an online face-to-face platform. The results of this study imply that the application of STEM-based flipped learning can be applied to courses that have a relationship with STEM subjects.

\section{REFERENCES}

Basal, A. 2015. The implementation of a flipped classroom in foreign language teaching, Turkish Online Journal of Distance Education, 16(4): 28-37 https://www.researchgate.net/profile/Ahmet-

Basal/publication/282890539_The_Implementation_of_A_Flipped_Classroom_i n_Foreign_Language_Teaching/links/562f892f08ae4742240afa61/TheImplementation-of-A-Flipped-Classroom-in-Foreign-Language-Teaching.pdf

Basham, J.D. \& Marino, M.T. 2013. Understanding STEM Education and Supporting Students through Universal Design for Learning. Sage Journals, 45(4):8-15 https://journals.sagepub.com/doi/pdf/10.1177/004005991304500401 
Bergmann, J., \& A. Sams. 2012. Flip Your Classroom: Reach Every Student in Every Class Every Day. United States: The International Society for Technology in Education (ISTE)

Bishop, J. L., \& Verleger, M. A. (2013). The Flipped Classroom: A Survey of the Research. 120th American Society for Engineering Education Annual Conference and Exposition, 30, 1-18 https://strategy.asee.org/22585.pdf

Damayanti H.N. \& Sutama. 2016. Efektivitas Flipped Classroom Terhadap Sikap Dan Ketrampilan Belajar Matematika di SMK. Jurnal Managemen Pendidikan. 11(2): 2-8 https://journals.ums.ac.id/index.php/jmp/article/view/1799/1251

Enfield, J. 2013. Looking at the impact of the Flipped Classroom Model of Instruction on Undergraduate Multimedia Student at CSUN. TechTrends. 57(6): 14-18 https://link.springer.com/article/10.1007/s11528-013-0698-1

Hamdan dan Knight, M. 2013. A Review of Flipped Learning. Virginia: George Mason University

Holmes, E.A., Arntz, A., \& Smucker, M.R. 2011. Imagery rescripting in cognitive behaviour therapy: Images, treatment techniques and outcomes. Journal of Behavior Therapymand Experimental Psychiatry, 38: 297-305. www.elsevier.com/locate/jbtep

Ilgu, A. K., Cherrez, N. J. dan Jahren, C. T. (2017). A Systematic Review of Research on The Flipped Learning Method in Engineering Education. British Journal of Educatiobal Technology, 00(00), 1-14.

Johnson, G.B. 2013. Student Perceptions of The Flipped Classroom. Columbia: The University of British Columbia

Lo, C.K., \& Hew, K.F. 2017. A critical review of flipped classroom challenges in K-12 education: Possible solutions and recommendations for future research. Research and Practice in Technology Enhanced Learning, 12(1)

Lou, S.J., Iu, Y.H., \& Shih, R.C. 2011. The senior high school students' learning behavioral model of STEM in PBL. International Journal of Technology and Design Education, 21(2): 161-183, https://link.springer.com/article/10.1007/s10798-010-9112-x 
Khan, W. dan H. Ullah. 2010. Scientific Reasoning: A Solution to The Problem of Induction. International Journal of Basic \&Applied Sciences IJBAS-IJENS. Vol 10(3) http://ijens.org/105303-9595\%20IJBAS-IJENS.pdf

Miles, M.B. \& Huberman. A.M. 2005. Qualitative Data Analysis (terjemahan). Jakarta: UI Press.

Maolidah, I.S., Ruhimat, T., \& Dewi, L. 2017. Efektivitas Penerapan Model Pembelajaran Flipped Classroom Pada Peningkatan Kemampuan Berfikir Kritis Siswa. Edutechnologia, 3(2): 160-170 https://ejournal.upi.edu/index.php/edutechnologia/article/view/9147/5684

Moore, T., Stohlmann, M., Wang, H., Tank, K., Glancy, A., \& Roehrig, G. (2014). Implementation and integration of engineering in K-12 STEM education. In S. Purzer, J. Strobel, \& M. Cardella (Eds.). Engineering in Pre-College Settings: Synthesizing Research, Policy, and Practices. West Lafayette: Purdue University Press.

Subagia, I.M. 2017. Penerapan Model Pembelajaran Flipped Classroom Untuk Meningkatkan Prestasi Belajar IPA Siswa Kelas X AP 5 SMK Negeri 1 Amalapura Tahun Ajaran 2016/2017. LAMPUHYANG, 8(2):14-25

Torlakson, T. 2014. Innovate: A Blueprint for Science, Technology, Engineering, and Mathematics in California Public Education. California: State Superintendent of Public Instruction.

Wijayanti, L. 2018. Buku Pedoman Akademik PGSD. Surabaya: Tidak dipublikasikan.

Zhou, G. Q., \& Jiang, X. F. 2014. Theoretical research and instructional design of the flipped classroom. In Applied Mechanics and Materials Trans Tech Publications Ltd 543:4312-4315 https://www.scientific.net/AMM.543-547.4312 